\title{
Könyvajánló: A lakosság egészségmagatartásának változtatása
}

\author{
Book review: Health Behaviour Change in Populations
}

Szerző: Varsányi Péter $\bowtie$

ELTE TáTK Egészségpolitika és Egészség-gazdaságtan Tanszék

Beküldve: 2017.09.05.

doi: 10.24365/ef.v58i3.176

Kulcsszavak: egészség; magatartásváltoztatás; lakosság; népegészségügy

Keywords: health; behavior change; population; public health

Scott Kahan, Andrea C. Gielen, Peter J. Fagan, Lawrence W. Green, Editors. Health Behavior Change in Populations. Baltimore, MD: Johns Hopkins University Press, 2014. ISBN-13: 9781421414553.

Napjainkban az egészségügyi szakemberek többsége egyetért azzal, hogy a lakosság egészségének javitásához elengedhetetlen az egyének egészséggel kapcsolatos magatartásának megváltoztatása. Az egészségesebb magatartás kialakítása legalább annyira fontos - ha nem fontosabb-, mint az egészségügyi ellátórendszer folyamatos korszerüsítése és szinten tartása.

A következőkben bemutatásra kerülő könyv ehhez az összetett és sokszereplős magatartásváltoztatáshoz szeretne segítséget nyújtani a népegészségügygyel kapcsolatosan tanulmányaikat folytatóknak, valamint a már gyakorló szakembereknek. „Az egyéntől nem várható el, hogy egészséges döntést hozzon, csak ha lehetősége van ezt megtenni. Számtalan stratégia áll a szakemberek rendelkezésére, hogy az egészséges döntés legyen az alapértelmezett" - írják bevetetőjükben a könyv szerzői, akik neves amerikai egyetemek (Johns Hopkins University, University of California at San Francisco) elismert népegészségügyi szakemberei és oktatói. Céljuk az volt, hogy a szakterületet érintő legfrissebb, bizonyítékokon alapuló információkat könnyen átlátható,

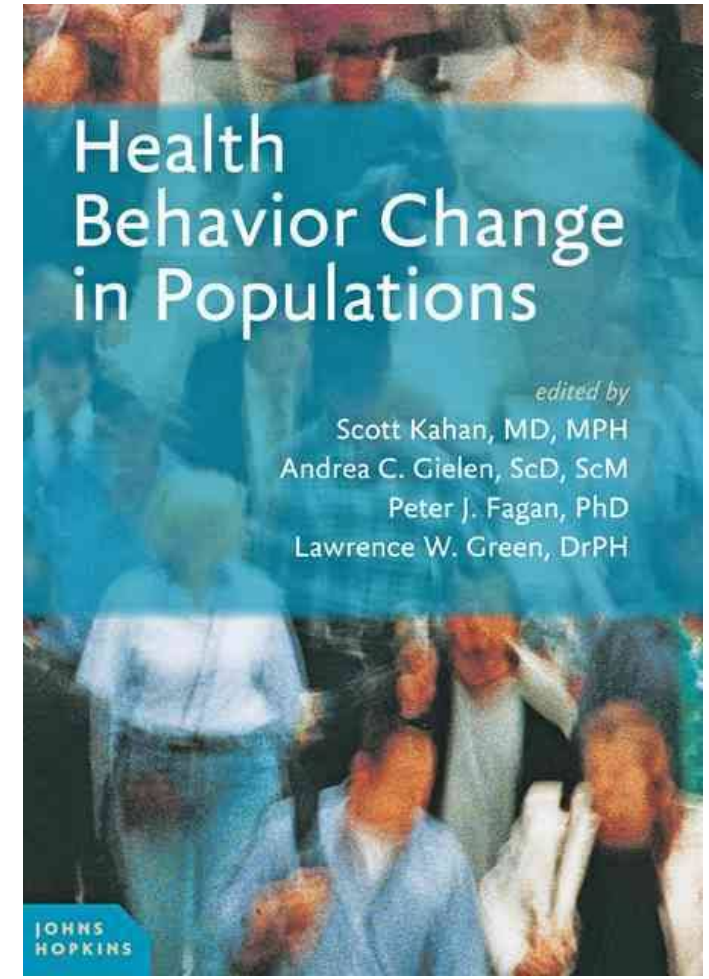

rendszerezett és felhasználóbarát formában tárják az olvasók elé. A könyv arra irányul, hogy megfelelő stratégiai alapelveket biztosítson a szakemberek számára a pozitív irányú lakossági szintú magatartásváltoztatás előmozdítására. Az elméleti háttér és a legfrissebb kutatások gyakorlati felhasználásának hangsúlyozásával a népegészségügyi szakembere- 
ket olyan szemléletmóddal ruházza fel, amely támogatja az egyéneket az egészségre irányuló döntések meghozatalában a megfelelő támogató környezet kialakításával.

A könyv három fő részből áll. Az első áttekinti azokat a magyarázó modelleket, amelyek hozzájárultak a magatartásváltoztatás tanulmányozásához egyéni és társadalmi szinten, így az olvasó kellő képet kaphat a szakterület időbeli fejlődéséről, komplexitásáról és a modellek mindennapi gyakorlatban való hasznosíthatóságáról. Mint ahogyan a szerzők írják, „azok az egészségmagatartás változtató programok, amelyek modelleken, bizonyítékokon és helyi ismereteken alapulnak, sokkal többet tesznek hozzá a szakterülettel kapcsolatos ismeretekhez és kutatásokhoz, mint azok, amelyek csak egy máshol sikeresen végzett program másolatai." Ehhez a szemlélethez nyújt alapvető ismereteket a könyv első része. A második rész a már ismertetett elmélet gyakorlati felhasználását mutatja, részletesen kitérve többek között az elhízás, dohányzás, alkoholfogyasztás, drogfogyasztás, sérülések népegészségügyi problémája és a tudományos bizonyítékokon alapuló magatartásváltoztatás kapcsolatára. A kiemelt rizikótényezők esetében áttekintésre kerülnek azok egészségterhei, kulcsfontosságú meghatározói és fogalmi keretei - beleértve az egyéni, családi, interperszonális, közösségi, szociokulturális és politikai perspektívákat is -, valamint a jelenleg ismert legfrissebb, bizonyítékokon alapuló beavatkozások és bevált, jó gyakorlatok különböző kulcsszereplők (például politikai döntéshozók, egészségügyi szakemberek, munkaadók, kutatók) vonatkozásában.

A harmadik részben további fontos népegészségügyi „határterületek” (például az egészségügyi ellátás, a betegkommunikáció, az egészségműveltség, az egészségkockázat-értékelés) magatartásváltoztatáshoz kapcsolódó problémájáról szerezhet információt az olvasó.

A könyv jól strukturált, könnyen áttekinthető, lényegre törő, nyelvezete érthető. Minden fejezet elején kiemelésre kerültek az adott rész kulcsüzenetei, így az is áttekintő képet kaphat a fejezetről, aki nem kíván annak részleteiben elmerülni. A könynyebb tanulást segíti továbbá a tankönyvhöz készült - a kiadó honlapján ingyenesen elérhető - diasor is, amely az oktatókat, valamint az egyéni tanulókat hivatott segíteni a tananyag elsajátításában. A könyv legvégén egy átfogó szószedet található, amely fontos segítséget adhat a területen dolgozó szakembereknek és a területtel még csak ismerkedő tanulóknak egyaránt.

„A lakosság egészség-magatartásának változtatása” olyan könyv, amely nagyszerú segítség lehet valamennyi népegészségügyi szakember számára, akinek fontos, hogy gyakorlatban is alkalmazható, a legfrissebb bizonyítékokon alapuló ismeretekre tegyen szert. A hazai népegészségügy helyzetét látva, fontos lenne, hogy a könyv minél több szakemberhez eljusson, és az abban szereplő szemlélet mielőbb meghonosodjon itthon is. Habár ez a könyv az USA-ban a népegészségügyi egyetemi képzés tankönyveként szerepel, biztos vagyok benne, hogy a hazai gyakorló szakemberek számára is elengedhetetlen információkat tartalmaz, amelynek megszerzésével és hasznosításával nagy lépéseket tehetnénk egy jobban múködő magyar népegészségügyi rendszer, és így egy egészségesebb magyar társadalom felé.

Jó olvasást kívánok! 